\title{
GONDOLATOK A MESTERSÉGES INTELLIGENCIA, A GÉPI TANULÁS KAPCSÁN
}

\author{
Szerző: \\ Gyarmati Péter (PhD, Prof.Emeritus) \\ Simonyi Professor for the Public \\ Understanding of Science and Professor of \\ Mathematics on the Computer Science
}

Szerző e-mail címe:

gyarmati@gyarmati.dr.hu

\author{
Lektorok: \\ Vámos Tibor (Prof. Dr. akadémikus) \\ MTA SZTAKI \\ Mező Ferenc $(\mathrm{PhD})$ \\ $\mathrm{K}+\mathrm{F}$ Stúdió $\mathrm{Kft}$.
}

...és további két anonim lektor

\begin{abstract}
Absztrakt
A mesterséges intelligencia és a gépi tanulás manapság a digitális technikákat fejlesztők mindennapos feladatai közé tartozik. Szinte naponta hallunk újabb és újabb csodákat, amelyeket robotok végeznek, számítógépi programokról, amelyek korábban megoldhatatlannak számító feladatokat oldanak meg. Vajon van-e, egyáltalán létezik-e elméleti megalapozása, tudjuk-e, lehetséges-e, hogy gépek gondolkozzanak? Izgalmas és mindmáig nyitott a kérdés. A tanulmány az evvel kapcsolatos érvek viták körébe vezeti be az olvasót.
\end{abstract}

Kulcsszavak: mesterséges inteligencia, gépi tanulás

Diszciplinák: matematika, informatika

\begin{abstract}
THOUGHTS ABOUT ARTIFICLAL INTELLIGENCE, MACHINE LEARNING

Artificial intelligence and machine learning are nowadays one of the daily tasks of digital technology developers. Almost daily, we hear more and more miracles performed by robots, and about computer programs that solve previously impossible-looking problems. Is there a theoretical foundation at all, do we know whether it is possible for machines to think? The question is exciting and still open. The study introduces the Readers about the arguments and debates of this issue.
\end{abstract}

Keywords: artificial intelligence, machine learning

Disciplines: matematics, informatics

Gyarmati Péter (2019): Gondolatok a mesterséges intelligencia, gépi tanulás kapcsán. Mesterséges intelligencia - interdiszciplináris folyóirat, I. évf. 2019/1. szám. 31-39.

doi: 10.35406/MI.2019.1.31 
„- Akkor ąt mondom, csinálj lehetetlent!

- Ha megmondod, mi az, a lehetetlen, akkor megcsinálom."

(Gyarmati Péter)

A gépi tanulás, a mesterséges intelligencia mindent elárasztó fontosságának és fejlesztésének korszakát éljük. Hatalmas verseny formálódik a gazdasági életben az eredményekből készíthető eszközök eladásának piaci részesedése terén - tökéletesen igazolva Neumann János egykori kijelentését, mely szerint „a fejlődés ellen nincs gyógymód” (Neuman, 1949): „A fejlődés ellen nincs gyógymód, a tudomány a jövőben inkább a szabályozás és vezérlés, a programozás, az adatfeldolgozás, a kommunikáció, a szervezés és a rendszerek problémáival törődik majd."..

Ahhoz, hogy megértsük ezt a mostani hatalmas érdeklődést érdemes visszatekintenünk a nem is távoli múltba, amely megalapozta mai tudásunkat.

“Tudnak-e a gépek gondolkodni?” merült fel a kérdés (Berkeley, 1949), mivel a számítógépek és társaik olyan tevékenységeket folytatnak, amelyeket az ember az agyával végez. „Egy gép információkat tud feldolgozni, számol, következtet és választ; az információkkal kapcsolatosan racionális múveleteket hajt végre. A gép tehát gondolkodni tud."

A kérdés, illetve az állítás annak idején rendkívül heves, sok esetben szélsőséges, szenvedélyektől túlfűtött vitát váltott ki. Ez érthető is, hiszen a kérdés mélyen gyökerező érzelmi és vallási meggyőződéseket is érint. Berkeley-vel szemben a másik szélsőséges álláspontot az egyház képviselte: a gép azért nem tudhat - elvileg - gondolkodni, mert a gondolkodás a lélek tulajdonsága, amely isteni eredetú. Ismét mások azt az álláspontot képviselték, hogy a gépek azért nem képesek gondolkodni, mert a gondolkodás lényegénél fogva az élő anyaghoz, az agyvelőhöz van kötve, a gépek pedig élettelen anyagokból állnak. A kérdés a szakembereket is mélyreható vizsgálódásokra késztette. Ezek során hamarosan kiderült, ahhoz, hogy a kérdésre válaszolni tudjunk, elóbb meg kell vizsgálni, mégpedig nemcsak általánosságban, hanem konkréten is, mit jelent tulajdonképpen a „gondolkodás” fogalma. Már a mottóban is felmerült az egzaktság hiánya, ami mindig valamilyen fogalmi területről ered.

A felvetett kérdésre nyilvánvalóan más és más felelet adható, aszerint, hogy milyen társadalom talaján, milyen szempontból, sőt milyen alapképzettségủ szakember igyekszik a választ megfogalmazni. A fiziológusok, feltéve, hogy a kérdéssel egyáltalán foglalkoztak, kissé tartózkodó, óvatos álláspontra jutottak. Stanley Cobb, angol fiziológus a következőket írja: „Az agy a tudat szerve. Az embernél az agyvelő hallatlan bonyolultsága az, ami a gondolkodást lehetôvé teszi, de az agyvelô anatómiájának és fiziológiájának bármilyen mélyreható tanulmányozása sem tudja önmagában megmagyarázni a tudatot. A gondolkodás olyan eseménysorozat, amely az agyvelő egyes részeiben, külső ingerek hatására keletkező, valamint más agyvelőkből érkező információk kölcsönhatásától függ." Ez 
a meghatározás azért érdekes, mert a gondolkodást reális - tehát anyagi -, a külvilágból érkező ingerekre reakcióként bekövetkező eseménysorozatnak fogja fel. Másrészt azonban éppen az agyvelő logikai szerkezetének bonyolultsága miatt eleve lemondó jellegü.

A. M. Turing angol matematikus már 1936ban kimutatta, hogy minden olyan számot (például valamely matematikai probléma megoldását), amelynek kiszámítására úgynevezett effektiv eljárást (mai szaknyelven szólva: algoritmust) meg tudnak adni, vagyis amelynél a számítási eljárást egyértelmű módon véges számú szabályba lehet foglalni, egy (akkor még csak hipotetikus) automata segítségével ténylegesen ki is lehet számítani. Az ilyen automatát azóta Turing-gépnek nevezik.

A számítógép vonatkozásában (vö.: Gyarmati, 2014) ugyanezt a tételt W. S. McCulloch (fiziológus) és W. Pitts (matematikus) úgy fogalmazta meg, hogy minden olyan eljárást, amelyet teljesen és egyértelmű módon szavakkal ki lehet fejezni, véges számú univerzális kapcsolóelem alkalmas kombinációjával meg is lehet valósítani (McCulloch és Pitts, 1943). Ilyen az élő idegsejt is, állítják.

Ebből viszont Neumann János vonta le azt a fontos következtetést, hogy a mindenkori technikai korlátokon belül a számítógépeket minden olyan művelet végrehajtására programozni lehet, amelyeket egyértelmű szabályokba lehet foglalni. Mindaz, ami szóbeli formában, szóbeli kérdések.kel kifejez̧hetó, realizálható is!
A. M. Turing, félretéve minden érzelmi és vallási motívumot, az összes lényeges körülmények számbavétele alapján a következő eredményre jutott: egy gépről akkor lehet azt állítani, hogy „gondolkodik”, ha egyértelműen meghatározott kísérleti feltételek között az ember által feltett tetszőleges kérdésre olyan módon tud válaszolni, hogy a kérdező arra a következtetésre jut, hogy azok embertől származnak. Eszerint a gondolkodás definíciója operatív, vagyis a kívülről megfigyelhető viselkedés ekvivalenciája.

\section{Ütköző nézőpontok}

A helyes kérdésfeltevés tehát nem az, hogy tudnak-e a gépek gondolkozni, hanem: milyen múveleteket lehet a gépbe programozni? Milyen fokon képes az adott gép gondolkodni? 1962-ben már sikerült a számítógépekkel logikai problémákat megoldani, matematikai tételeket bizonyítani. Úgy gondolták, hogy az évszázad végére nyugodtan beszélhetünk majd gépi gondolkodásról anélkül, hogy ez bármiféle ellentmondást váltana ki annak ellenére, hogy számosak az ellenvélemények.

Érdemes ezeket áttekinteni, és az alábbiakban meggondolásra ajánljuk:

1. Teológiai ellenvetés. A gondolkodás az emberi lélek funkeciója, isten adta, de nem adta azt egyetlen más állatnak, vagy gépnek sem.

Ellenérv ezzel szemben, hogy az Ótestamentum szerint bizonyos állatoknak szintén van lelkük. A lélekhez pusztán meg- 
felelő agyvelővel kell ellátni, amely mutáció kérdése csupán. Aztán itt van még, hogy a mohamedán nézet szerint a nőknek nincs lelkük. Végül a teológiai érvek csak addig élhetnek, amíg a kellő természettudományos tudás nem áll rendelkezésünkre.

2. Struccpolitika. A gondolkodó gépek következményei beláthatatlanok, reméljük ilyen nem fog bekövetkeqni. Az ok az emberi felsöbbrendüség érzete, illetve elvesztésének félelme.

A valóság, hogy az üzleti viszonyok mit sem törődnek bármilyen félelemmel, következménnyel, a fejlődést nem lehet megállítani.

3. Matematikai ellenvetés. A disqkét állapotú gépek teljesitöképességének korlátai vannak. A Gödel-tétel értelmében bármely elegendöen teljesitó képes logikai rendszerben lehet olyan állitásokat megfogalmazni, amelyeket a rendszeren belül sem megcáfolni, sem bizonyitani nem lehet, kivéve, ha maga a rendszer ellentmondást tartalmaz. (Gödel, 2003). A következmény, hogy a logikai gép válasza hibás lesz, vagy egyáltalán nem válaszol.

Ellenérv, hogy ugyan az emberi eleme mindig képes válaszolni, de vajon mennyi a hibás a válaszok között. Nyilván vannak emberek, akik okosabbak egy adott gépnél, de nyilván vannak, lehetnek olyan gépek, amelyek nála okosabbak és így tovább.
4. Öntudat. Mindaddig, amig egy gép nem tud szonettet, vagy koncertet irni az átérzett gondolatok alapján, hanem tisztán a squimbólumok véletlen elrendezése következtében, nem tudunk egyetérteni azzal, hogy a gép egyenértékeu az agyvelövel, amely nem csak megirja, hanem tudja is, hogy megirta. Semmiféle mechanizmus nem tud örömet érezni sikere fölött (mesterséges jelrése olcsó ötlet lenne).

Nyilván vannak különböző szintű korlátok, miként az fennáll az embereknél is. Ha A azt hiszi, hogy „A gondolkodik és B nem”, továbbá, ha B úgy gondolja, hogy „B gondolkodik és A nem", és ezen vitáznak, akkor csak azt tehetjük fel, hogy mindenki gondolkodik - különben nem lehetne vita. Nem arról van szó, hogy valaki, vagy valami papagáj módjára betanult szöveget ad elő.

5. Képességek hiánya. Lehetséges, hogy az összes emlitett dolgokat végrehajtó gépet lehet csinálni, de sohasem tudnak olyat, amely bármely $X$ dolgot végre tudna hajtani. Itt $X$ alatt sqámos tulajdonságot lebetne emliteni, például a gép legyen kedves, segitókész, szép, barátságos, legyen bumorérzékee, sz̧eresse a tejszines epret, ébresszen szerelmet, stb..

Valóban, gépeink többsége csúnya, a célnak éppen megfelelő kivitelűek, a cél változására reagálni képtelenek, stb.. A miniatürizálás, a nanotechnológia, új anyagok felfedezése lehetőséget adott nagy kapacitású és gyors eszközök fejlesztésére, amelyek már meglehetôsen függetlenek külső formájuktól, tehát lehetnek akár szépek is. Elegendő memóriá- 
val rendelkeznek, képesek emlékezni, tanulni, sőt az emberi agynál lényegesen nagyobb kapacitással és sebességgel, mi több pontosan, és megbízhatóan múködnek. Láthatjuk, nincsenek határok, pusztán az elért eredmények hiányosak. Van még bőven teendő és evvel együtt lehetőség.

6. Tévedés joga. A gépek, alkotásuk értelmében, tévedhetetlenek. Ha nem igy lenne, nem alkalmaznánk öket. Természetesen nem a meghibásodásról van itt sqó.

Mondatnánk, hogy ez miért baj? Elméletileg egy megoldás változatairól van szó, amelyek értéke különböző lehet, például helyes, kevésbé helyes, kielégítő, valamilyen értelemben rossz, téves. A gépi tanulás képességétől kezdve megállapíthatjuk, hogy a gép is juthat különböző következtetésekre, miként az ember is ilyen alapon téved, mivel a tanult dolgok más környezetből származnak, mint alkalmazásuk.

7. Lady Lovelace (öt tartjuk az elsô gépi programozónak, a Babbage által kifejlesztett analitikus gépen) felvetése. A gépek nem képesek kezdeményezni, üjat alkotni.

Az ellenvetés legelőször az, hogy a kijelentés kizárólag a rendelkezésére álló, megfigyelt eszközökre vonatkozhatott.

Másodsorban a kérdés: vajon képes-e egy gép meglepetést okozni, azaz olyat tenni, amire nem számítottunk? Nyilvánvalóan, például amikor kiderül, hogy bizonyos feltételezésem, számításom nem volt helyes, mert a gép más eredményt hozott ki, vagy adatbázisából már tudja és közli, hogy elfogyott a színházjegy, de a következő előadásra tud szerezni. Az alapja a mindig aktuális adatbázis - onnan vásárol mindenki belépőt. Tehát a gép tudja, mi nem, a gép szólhat, ha minket érdeklő előadás lesz.

8. Folytonos és diszkerét ellentmondása. Az embert a környezeti hatások folytonosan érintik, és azokra folytonosan reagál. Disұłkrét módon a reagálásban kiesések lesznek.

A felvetés óta a neurológiában elért felfedezések az agyvelő diszkrét működését bizonyították. Ahol szükséges az idegek képesek folyamatosan fenntartani a jelzésüket. A gépek is teljesen alkalmasak erre: a vezérlés, a szabályozás diszkrét, a beavatkozás folytonos. Szinte minden kibernetikai rendszer így épül fel.

9. A viselkedés kötetlensége. Lehetséges-e olyan szabálygyüjteményt késziteni, amely az ember, a társadalom számára leirná, hogy bármilyen esetben mit csináljon, hogyan viselkedjen? Ha ez igy lenne, akkor az ember is gép lenne, pedig az ember nem lebet gép!

Ellenérv az, hogy a természet, a természeti törvények szabályoznak bennünket teljes egészében, hiszen annak részei vagyunk, mégsem tartjuk magunkat gépeknek. Tudjuk 
viszont, hogy politikusaink, jogászok és mások igénybevételével, erősen „dolgoznak” mindenféle viselkedési szabályok minél teljesebb megfogalmazására. Mindennapos kifejezés a „zéró tolerancia”. Szerencsénkre ez eddig még nem sikerült. Ha csak az erőszak a megfelelő módszer, ahhoz viszont nem kevés csodagéppel kell rendelkezünk: hadi eszközökkel és módszerekkel.

10. Percepció az érzékeszerveken túl. Telepátia, gondolatolvasás, elörelátás, akaratátvitel jelenségei még a tudományos felfogásunkat is ravarja, nem hogy gépet készithessünk ilyen célra.

A percepció más jellegű alkalmazásának egyik fon-tos eleme a hálózatok létrejötte. Nagyon széles skálában ma is kaphatunk kérdéseinkre úgy és olyan választ, amelyek túl vannak érzékszerveink képes-ségén. Már csak a mumusok, kísértetek hiányoznak onnan, talán még ezeket is képes lesz a jövő nem-zedéke előállítani és a világhálón megjeleníteni.

11. Természetes út. A természetnek néhány millió évbe került az emberi intelligencia létrehozása. Vajon az embernek - figyelemmel a felgyorsult tudományos-technikai fejlódésre és eredményeire mennyi idöbe telik a mesterséges intelligencia kiteljesitése egészen az emberi intelligencia szintjéig? Egyáltalán képes lesz-e erre?

A természet a sokféleséggel, a mutációval, és jelentôs környezetváltozásokkal oldotta meg ezt a feladatot. Az élő egyedek szaporodnak, reagálnak a környezetükre és energiaforgalmú működési ciklusuk van. Az élő utánzására legalább e tényezők mesterséges megvalósítása szükséges.

Az egyedek a környezettel és egymással való kapcsolatukból tanulnak és ennek bizonyos részeit a szaporodás során tovább örökítik, valamint a mutáció révén továbbfejlesztik, változtatják. Ami ebből ,tudatos”szándékos célzatú azt nevezhetnénk fejlesztésnek, a többi változás véletlenszerū, ez hozza létre a sokféleséget. Ez a definíció talán nem így pontos, de mindenképen a szaporodás során egymásra épülő környezeti tapasztalatszerzés és a mutáció hozta és hozza létre a törzsfejlődést, melynek kirívó esete az emberi agyvelő. Mai, legjobb tudásunk szerint ez a mi természet adta képességünk, amely a tudás, az intelligencia, az öröklés, a tapasztalatszerzés és a tanulás útján jön létre. Tehát az intelligencia minden egyes emberben az élete során kialakuló folyamat és annak eredménye!

Egy apró kis hiba van azonban ebben az okfejtésben, nevezetesen az öröklés során az agyvelőbe „beépülő” intelligencia rész. Ezt részben magyarázhatjuk az ősök, elődök által szerzett tudás tovább örökítésével, de az első ilyen öröklés, vagy annak képessége már vitatható. Isten, avagy valamilyen teremtő eredetű-e, esetleg a természet játéka, vagy véletlen? Frankensteint és társait az ember teremtette, de mindenkor érezték az „éltető szikra” szükségességét, hozzáadását, amely nélkül lelketlen, holt dolog marad (Mary Shelley „Frankenstein, avagy a modern Prométhe- 
usz" című regényét 19 évesen írta 1816-ban; a mû 1977-es, elsô magyar fordítása Göncz Árpád munkája). A modern irodalom is odáig jut, hogy bárminemû mesterséges intelligencia megvalósítható, de az, az ember nélkül teljességgel értelmetlen marad.

\section{Ember és gép együttmüködése}

A mesterséges intelligencia magas fokának inkább a veszélyét jelzik, amikor is a gépek uralkodóvá válnak és az ember ellen fordulnak. Nyilvánvaló feltételezés ez, hiszen az emberek is állandóan egymás ellen fordulnak. Ez egy kettősség, ami régóta létezik a világunkban, egyrészről bizonyos intelligenciával ellátott eszközöket alkotunk, másrészről törvényekkel, szabályokkal, előírásokkal rábízzuk, azaz ezen eszközök „fennhatósága” alá rendeljük magunkat, valamilyen érdekből kifolyólag. Például, ha az autó motorja jár, akkor a fedélzeti vezérlő számítógép bezárja az ajtókat valamilyen meggondolt védelmünk érdekében. Semmilyen kérésre nem nyitja ki, kizárólag a saját programja előírásai szerint fog cselekedni. Még súlyosabb példa az a terjedő nézet, hogy egyre kevesebb dolgot kell megtanulnunk, mivel - szükség esetén - azt a „gép tudja” és mindig rendelkezésünkre áll. Ez mindaddig megfelelő lehet, ameddig a gép a cselekvő és azt biztosan és mindig helyesen teszi. De valóban így van/lehet ez minden alkalommal? Mert ha mégsem, akkor ki veszi észre és ki változtat rajta? Hiszen a „tudás” a gépben van!

Az ellenvetések ellenére, tehát megállapíthatjuk, hogy a gépek képesek gondolkodni, alkalmasak olyan dolgokra, viselkedésre, melyeket eddig csak az embernek tulajdonítottunk. Igaz, azt is tudjuk, hogy ez nem egy darab komplett gépet jelent, de hát az emberiség sem pusztán egy, hanem teljes társadalom. Azt is megtudtuk, hogy miként az ember nem tévedhetetlen, úgy a gép sem mindig az, kivéve, ha ez a kifejezett szándékunk, miként azt az automatáktól elvárjuk. A gép is mindig az adott környezetben tanul és alkalmazza a tapasztalatait.

Ez az állítás újabb kérdéseket vet fel!

Vajon a gondolkodás valóban mindenféle algo-ritmusok bonyolult együttmúködésének eredménye, vagy itt is létezik egy bizonyos „minőségi ugrás”, amely elválaszt, miként az, az élő és élettelen között az eddigi legjobb ismereteink szerint fennáll?

A kérdésre adandó válasz nyitott, azonban ez nem akadályozhatja az ember világának mindenek feletti fejlődési szándékát, jelen esetben a gépi tanulás, a mesterséges intelligencia, a robotika, az antropomorf eszközök egyre magasabb fokú fejlesztését.

A választ állandóan keressük és rész megoldásaink is vannak. Neumann János (1955) egy tanulmányában ezeket írja: „Az emberi értelem sok olyan tulajdonsággal rendelkezik, amelyeket nem lehetséges automatikusan megközelíteni. A logika ezen típusa, amelyet általában az »intuitív« szóval jelölnek, olyasmi, amiről még rendes leírásunk sincs. A legjobb, legtöbb, amit tehetünk, hogy felosztjuk az összes folyamatot olyanra, amelyeket a gépek és olyanokra, amelyeket az emberek tudnak elvégezni; és azután kitalálunk módszereket, amelyekeel ez a kettö összekapcsolhato’. Ma is így gondoljuk, ez 
a fejlődés útja: célunk van, feladat van, a végső megoldás talán nem lehetséges, de nem is szükségszerū.

\section{Remények és eredmények}

A gondolkodó gép eszméjének megszületése azonnal reményeket adott az intelligencia gépesítési álmához. Az első mesterséges intelligencia kongresszus terve 1955-ben merült fel (McCarthy és tsai, 1955) és a rendezvényt 1956-ban Dartmouthban tartották és a LISP első változata már 1958-ban elkészült.

Deklaratív, nem utasítás, jellegű programnyelvek: a LISP, az ERLANG, a PROLOG, az SQL, bizonyos értelemben a HTML-k és társaik. Ezek a mesterséges intelligencia logikájának megfelelőek.

A remény hamar szertefoszlott, kiderült, hogy az emberi okoskodás bármilyen leírása pusztán logika, sőt abban a pillanatban, hogy elkezd gépen mûködni, algoritmussá válik, tehát nem intelligencia többé.

$\mathrm{A} z$ algoritmus nem intelligencia, hanem állapot szekvencia, vagy rekurzor, amint arról a számítástudományi szakirodalomban bőven olvashatunk. Tipikus példa a perceptron (Gyarmati, 2011), amely pusztán a neuron közelítése mesterséges modellel, s távol van egy bizonyított definíciótól. Kétségbeesésre azonban nincsen semmi ok, mivel az eredmény - a perceptron modell és változatai - számos területen jól alkalmazható eszköz: felismerő- és kereső algoritmusok, stb. területén.

A karakter-, a beszéd-, a nyelv-, a kép felismerés voltak a kezdetek feladatai, amelyek több-kevesebb buktatóval még ma is feladatnak tűnnek. Számos eredményt ért el még a mesterséges intelligenciából fakadó technika, elsősorban a kognitív tudományok területén a szakértői rendszereken át, a statisztikus elméleteken keresztül, amely a robotikával, az adatbányászattal, az automatika kérdéseivel, egészen az ember-gép kapcsolat beszélő és beszéd felismerő csodákig terjed.

Közismert a hasonlat, hogy az intelligencia a forma-homok az öntéskor, a mesterséges intelligencia a mara-dék a homok eltávolítása után. Éppen a mesterséges intelligencia a bizonyíték arra, hogy az intelligencia jelen volt. $\mathrm{Az}$ intelligencia elmaradhatatlan, még ha pillanatai voltak csak.

\section{Zárógondolatok}

Nem szunnyad a „Gondolkozik-e a gép?” kérdés, legfeljebb más, újabb formákban jelenik meg: talán nem is csak egy út - az emberi - létezik az intelligenciához, szólnak a legújabb gondolatok.

Bizonyos vagyok benne, hogy a mesterséges intelligencia területe mindig megújul (vö.: Russel és Norvig, 2003), képes az újabb kihívásoknak eleget tenni és hasznos dolgokra fordítani, az elért eredményeit. Ugyanakkor ne feledjük a veszélyeket, amelyeket éppen az ember képes gépeibe beleépíteni, vagy szándékosan esetleg szándéktalanul is beavatkoz- 
ni legtöbbször valamilyen érdek alapján és minden humán felelősség mellőzésével. A tudósok mellett, most már a technikusnak - a programozónak, a mesterséges intelligencia építőjének és művelőjének - is hatalmas a felelőssége.

\section{Irodalom}

Berkeley, E.C. (1949): Giant brains or Machines that think. New York (USA) : John Wiley \& Sons Inc.

Gödel, K. (2003): Néhány tétel a matematika megalapozásáról és ezek következményeiről. In Csaba Ferenc (szerk.)(2003): A matematika filozófiája a 21. szárad küszöbén. Osiris Kiadó, Budapest. 61-88.

Gyarmati, P. G. (2011): Some words about networks, ch.17. Perceptron pp. 117-122. TCC COMPUTER STUDIO

Gyarmati, P. G. (2014): A contribution to the Hungarian computer history, 1958-1968. Letöltés: 2019.07.20. Web: http://www. freeweb.deltha.hu/gyarmati.dr.hu/compu ter/computer-saga.pdf

McCarthy, J., Minsky, M., Rochester, N. \& Shannon, C. (1955): A Proposal for the Dartmouth Summer Research Project on Artifi-cial Intelligence. Letöltés: 2019.05.10. Web: http://www.formal.stanford.edu/jmc/his tory/dartmouth/dartmouth.html.

McCulloch, W.S. \& Pitts, W. (1943): A logical calculus of the ideas immanent in neurons activity, Bull. Math. Biophys., 1943, vol. 5, pp. 115-133.

Neumann, J. von (1955): The Impact of Recent Development in Science on the Economy and Economics. (speech delivered) published in: Looking Ahead, 1956, No. 4, also in Bródy, A. \& Vámos, T. (eds.) (1995): The Neumann Compendium. London (GB): World Scientific

Neumann J. (1965): A legújabb tudományos fejlõdés hatása a gazdaságra és a közgazdaságtanra. In Neumann János: Válogatott elõadások és tanulmányok. Közgazdasági és Jogi Könyvkiadó, Budapest. 100-102.

Neumann János (1965): Válogatott elóadásoke és tanulmányok. Közgazdasági és Jogi Könyvkiadó, Budapest.

Russell, S. J. \& Norvig, P. (2003): Artificial Intelligence: A Modern Approach (2nd ed.), Upper Saddle River, New Jersey: Prentice Hall.

Turing, A. (1950): Computing Machinery and Intelligence. Mind, LIX (236): 433-460, doi: $10.1093 / \mathrm{mind} /$ LIX.236.433 